\title{
Haemophilus influenzae, Beta-Lactamase Negative
}

National Cancer Institute

\section{Source}

National Cancer Institute. Haemophilus influenzae, Beta-Lactamase Negative. NCI

Thesaurus. Code C123477.

Any bacterial species identified as Haemophilus influenzae that does not produce the enzyme beta-lactamase. 